\title{
Solid-liquid anaerobic baffled reactor treating food waste
}

\author{
Indro Sumantri ${ }^{1}$, Ika Bagus Priyambada ${ }^{2}$, Hadiyanto Hadiyanto ${ }^{1}$ \\ 1Chemical Engineering Department, Faculty of Engineering, Diponegoro University, Semarang, Indonesia \\ 2 Environmental Engineering Department, Faculty of Engineering, Diponegoro University, Semarang, Indonesia
}

\begin{abstract}
The characteristics of the sauce industrial wastewater is high organic degradable materials, it requires adequate treatment in order to process wastewater is technically and economically feasible. The main treatment to remove high content of organic material is anaerobic process. The presence of a preservative agent in wastewater would lead to disruption of the growth of micro-organisms. Slow the growth of anaerobic bacteria require a solids residence time (solid retention time, SRT) period in anaerobic reactors. This research is to observe the effect of input COD with constant sludge height to the removal of COD. Main equipment process of anaerobic reactor is baffled reactor. Activated sludge used are obtained from the tofu and tempe wastewater treatment unit in Semarang while synthetic wastewater was obtained from dissolution of preservative material product (Del monte sauce). The control parameter was: $\mathrm{pH}$, alkalinity, the ratio of COD: N: P, baffled configuration, wastewater flow rate (20 L/day), addition of micronutrient and height of suldge. The variable of reseach was initial COD input. The observed response is: COD removal and $\mathrm{pH}$. The total COD removal for low organic loading $(2369.7 \mathrm{mg} \mathrm{COD} / \mathrm{L})$ is 80.36 to $98.03 \%$ and for high organic loading $(7334 \mathrm{mg}$ COD/L) is 98.15 .
\end{abstract}

\section{Introduction}

Currently, in Indonesia, there are about 24 companies which produce tomato sauce and/or chili sauce compared to 2003 which only 16 companies. The process production ofthis supplementary food is a simple process and also the availability of abundant raw materials make these products often encountered with various brands and quality which can not be accountable. Even sometimes the sauce product is often forged by using dangerous raw materials [1]. In Indonesia, there is a various range of products which are a good sauce manufacturer both modern process and the local products. Process production in modern industry usually uses materials concentrate [2] while the local products more tend to utilize from its original raw materials because of the abundant raw materials or the use of a low economic value raw materials.

Research conducted by several institutions indicates that the local products of sauce, soy sauce and spicy show that six of the nine brands of chilli sauce researched were obtained sodium benzoate preservative containing more than $1,000 \mathrm{mg} / \mathrm{kg}$ [3] as the value of the threshold limit the use of sodium benzoate on the sauce according to regulation of Ministry of Health Number 033 in 2012. While, in a locally sweet soy sauce products, test the content analysis of the preservative sodium benzoate for eight brands of the products examined, six of which contain preservatives exceeding the maximum limit allowed namely $600 \mathrm{mg} / \mathrm{kg}$ [3]. Table 1. indicates the levels of sodium benzoate is present in the ketchup and soy sauce products local products.

Table 1. The content of sodium benzoate in the local products of ketchup and soy sauce [4]

\begin{tabular}{|c|l|c|c|}
\hline No & \multicolumn{1}{|c|}{ Brand } & Location & $\begin{array}{c}\text { Content of } \\
\text { sodium benzoat }\end{array}$ \\
\hline Soy sauce product & Makassar & $4.656 \mathrm{mg} / \mathrm{kg}$ \\
\hline 1 & Sumber Agung & Batam & $3.114 \mathrm{mg} / \mathrm{kg}$ \\
\hline 2 & Cap Cabe Payung & Surabaya & $2.165 \mathrm{mg} / \mathrm{kg}$ \\
\hline 3 & Tri Sari & Medan & $1.311 \mathrm{mg} / \mathrm{kg}$ \\
\hline 4 & Cap AVE & Jakarta & $1.353 \mathrm{mg} / \mathrm{kg}$ \\
\hline 5 & Sari Nikmat & Medan & $1.231 \mathrm{mg} / \mathrm{kg}$ \\
\hline 6 & Cap Captain & Makassar & $1.037 \mathrm{mg} / \mathrm{kg}$ \\
\hline 7 & Saus tomat Sumber & Surabaya & $1.601 \mathrm{mg} / \mathrm{kg}$ \\
\hline 8 & Jaya & \multicolumn{3}{|l}{} \\
\hline Ketchup product & Makassar & $802 \mathrm{mg} / \mathrm{kg}$ \\
\hline 9 & Ayam Panggang & Semarang & $1.276 \mathrm{mg} / \mathrm{kg}$ \\
\hline 10 & KOKI & Surabaya & $1.109 \mathrm{mg} / \mathrm{kg}$ \\
\hline 11 & Ikan Bawang & Padang & $1.194 \mathrm{mg} / \mathrm{kg}$ \\
\hline 12 & Burung Bangau & Medan & $2.103 \mathrm{mg} / \mathrm{kg}$ \\
\hline 13 & Panah Sinar Langkat
\end{tabular}

The addition of a food preservative substance is a prevention efforts or hold so that the food does not produce odor, this is done by changing the availability of chemical composition of the foodstuff, the addition of chemicals known as preservatives and anti-oxidants or by certain biochemical processes (fermentation) to

\footnotetext{
*Corresponding author: indrotekim@yahoo.com
} 
produce preservative compounds. The use of chemical preservatives have been practiced by humans since antiquity. Salt, fogging, the use of acidic vinegar and cooking meats with nitrates are an example of the preservation techniques of those used to be based on the addition of preservatives. Preservation of drinks with alcoholic fermentation and lactic fermented milk with a previous preservation practices are based on the conditions of preservation through biochemical processes [5].

Benzoic acid, $\mathrm{C} 6 \mathrm{H} 5 \mathrm{COOH}$, and its derivatives is a food preservative which is most widely used. Benzoic acid has a low solubility in water, sodium benzoate is a commonly used form. However, only molecules that do not dissosiate have anti-microbial properties. Therefore active benzoic only at low $\mathrm{pH}$, under 4.5. Concentrations commonly used ranges from 500 to $2000 \mathrm{ppm}$ such as: to preserve fruit juices, vegetable juices, vegetable, olive pieces. The use of benzoic acid at low $\mathrm{pH}$ is meant to mold and decay fungi but not for bacteria. In fact, the damage because the bacteria are somewhat resistant to benzoate. The use of sodium benzoate in foods on the above mentioned range permitted by many countries [5].

For health, the consumption of excess sodium benzoate can cause stomach cramps, numb fingers taste mouth for people who are tired. This nature accumulative preservative properties could also cause cancer in the long period of time and there were also reports indicating that these preservatives can damage the nervous system [6]. Research on the use of sodium benzoate as a preservative against the effects of genetic damage (genotoxic effects) in a laboratory with a concentration $6.25-100 \mu \mathrm{g} / \mathrm{mL}$ produces that sodium benzoate is compound clastogenic, mutagenic and cytotoxic against lymph cells of man [7].

In the process of food complement production both sauce and soy sauce will be produced wastewater. Wastewater sauce and ketchup are classified in food waste and easy to degrade. Food industry wastewater has characteristics of high levels of COD $(16,000>\mathrm{mg} / \mathrm{L})$ [8], suspended solids, dissolved organic compounds, microorganisms and inorganic salts [9], and the ratio $\mathrm{BOD} / \mathrm{COD} \geq 0.5$ [2]. Based on the content of waste organic compounds is high, then the processing treated with biological process. The main biological processes used are anaerobic biological processes because of the high removal efficiency but it still does not meet threshold quality of raw water so enhanced aerobic processes to meet existing quality raw water.

Based on operational considerations between aerobic and anaerobic processes such as organic load, rate of production of sludge, nutrient needs, energy requirements and energy generated [10] as well as the ratio $\mathrm{BOD} / \mathrm{COD} \geq 0.5[11]$ then the waste water treatment system with the preservative material selected material is anaerobic. Anaerobic digestion has been known since decades ago, the use of microbes in a condition without the presence of oxygen molecules and there is a large amount of organic compounds. An organic compound is a food source for microbes and convert it into oxidized compounds, new cells, energy, for the life of the process, and some of the results of the compounds in the form of gases such as methane and carbon dioxide.

On the anaerobic process, complex organic waste will be degraded into methane, carbon dioxide and water through three main steps (hydrolisis, acetogenesis and methanogenesis including asidogenesis) in the absence of oxygen. Anaerobic processes have gained rapid progress especially for wastewater treatment based on concept retrieval and utilization of resources as well as the fulfillment of the condition in the control of pollution $[12 ; 13]$.

The main problem in anaerobic processing is contact between an existing wastewater with sludge in a digester or reactor. The better the contacts then it will be the less time consumes, the less time is required then it will be the smaller the dimension of the digester required to be built. Construction of stirred flow reactor requires a depth of up to $5 \mathrm{~m}$, it will be difficult if its area has a shallow well water sources. Periodical anaerobic baffled reactor $(\mathrm{PABR})$ reactor requires special construction because of the shape of a circle. Therefore the design of anaerobic baffled reactor intended to overcome the lack of contact between the wastewater with sludge and also its construction does not require the high depth.

Advantages of anaerobic baffled reactor (ABR) is : simple design, without mechanical stirring, reduce the occurrence of blockage, and the cost of operation and low maintenance. For biomass used: does not require the presence of granular sludge biomass, requires no special deposition with low growth, solid sludge retention time is high, does not require a fixed media and does not require a specific gas or solid separation. Review of operation: low liquid residence time, allowing operation in intermitten, stable against hydraulic shock loads, long operation without disposal of sludge, high levels of stability against organic shock load.

Application of anaerobic technology for processing wastewater industry depends on the development and utilization of high-rate anaerobic bioreactor. Amongs the high rate of the reactor, anaerobic baffled reactor (ABR,) has been suggested as a promising system for the processing of wastewater industry. Anaerobic baffled reactors already are widely used to process industrial wastewater of palm oil mill [14], swine wastewater [15], leachate of pulp and paper mills [16], azo dye, landfills wastewater, leachate of synthetic wastewater with a content of sulphate and chromium (III) [17], wastewater of distillate liquors [18], wastewater contains nitrogen [19], liquid waste containing sulfate [20], liquid waste of textile dyes [17], wastewater containing p-nitrophenol [21], an alcoholic wastewater [22] and also domestic wastewater [17] and the wastewater of antibiotics [23].

The reactor consists of a number of the UASB reactor connected in series. Wastewater will flow above and below the vertical baffle when the flow enters the reactor. The unique design of the baffle of the ABR was able to reduce the loss of biomass so that it generates the very active biomass content. ABR can quickly recover remarkably from a load of hydraulic and organic shock, requires no special equipment to separate active sludge and gas [24]. 
Existing configuration $\mathrm{ABR}$ allows functions as a two-phase anaerobic treatment system with biomass separation of acidogenic and methanogenic. The reactor has a simple form and specifically does not require equipment of the separation of gas and active sludge and can be applied for almost all the dissolved organic wastewater from low to high organic content. Consideration of the a simple structure and operations, these can be considered as a potential reactor systems for urban waste water processing in tropical and sub-tropical countries for developing countries [25].

Anaerobic baffled reactor, ABR. First developed by McCarty [26] and friends of the researchers, consisting of compartments with divider multilevel, wastewater will flow down contact with active sludge, passes through the baffle and up flow through the blanket of anaerobic sludge. These reactor requires no active to granulated effectively. Very stable to shock load to (changing) because the compartment structure. Other benefits are: does not require biomass with specific properties to deposition, the cost of construction and operations. Based on the design of the reactor then ABR resembles a good mixing with reactor or ABR reactor resemble stopper (plug-flow reactor).

\section{Materials and Methods}

\subsection{ABR design}

A lab-scale transparent ABR bioreactor was fabricated using plexi glass sheets and designed has 3-pairs down and upflow with $60 \mathrm{~cm}$ of length, $25 \mathrm{~cm}$ of wide, $40 \mathrm{~cm}$ of height, $10 \mathrm{~cm}$ of distance between baffles, $1,5 \mathrm{~cm}$ of distance of baffle and bottom reactor and total volume of 60 L. The ABR consisted of three pair equal compartments and each compartment had a pair of baffles of downflow and upflow (hanging and standing baffles) and sample ports.

The temperature difference of inside reactor, due to the changes in the temperature during the day and night wass less than $3 \mathrm{oC}$. Therefore, the reactor did not require cooling or heating system to maintain the temperature. A peristaltic pump was used to feed the ABR with synthetic wastewater.

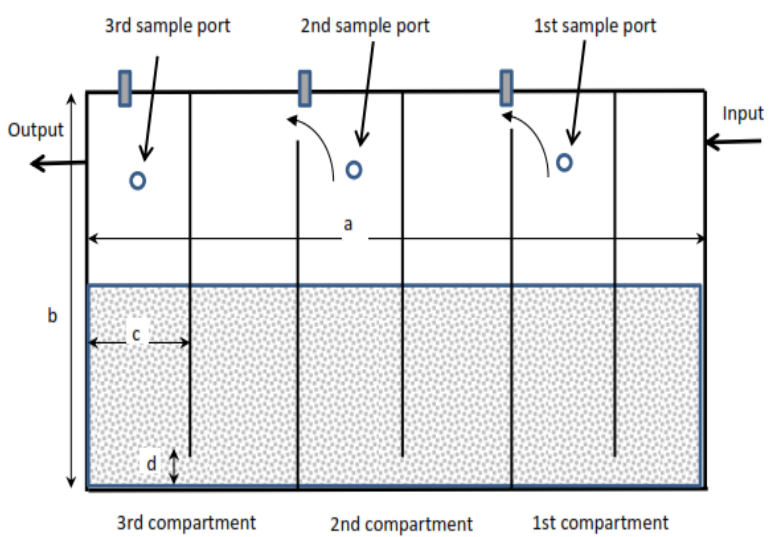

Fig. 1. Anaerobic baffled reactor $(A B R)$ and its baffles with dimensions $(\mathrm{cm}) \mathrm{a}=60 \mathrm{~cm} ; \mathrm{b}=40 \mathrm{~cm} ; \mathrm{c}=105 \mathrm{~cm} ; \mathrm{d}=1.5$ cm; wide: $25 \mathrm{~cm}$ [27]

\subsection{Sludge preparation}

Anaerobic sludge obtained from Centralized of Wastewater Treatment plant of small scale tofu industries at Lampertengah, Semarang Municipality. Anaerobic sludge was taken by water sampler in the middle of anaerobic reactor. Sludge was set up into the reactor with certain height $50 \%$ of reactor height. The sludge preparation was conducted by synthetic wastewater of $2 \mathrm{~g} / \mathrm{L}$ of sucrose, $\mathrm{pH}$ (7.5), $\mathrm{Ca}^{++}$ion (40 $\mathrm{mg} / \mathrm{L}$ ), and addition of macro nutrients of $\mathrm{N}$ and $\mathrm{P}$ with rasio of COD : $\mathrm{N}: \mathrm{P}$ of $300: 5: 1$, and micro nutrients with composition of (per g COD) [28] : Co $(500 \mu \mathrm{g}), \mathrm{Cu}$ $(300 \mu \mathrm{g}), \mathrm{Fe}(4000 \mu \mathrm{g})$, Mo $(150 \mu \mathrm{g}), \mathrm{Ni}(6000 \mu \mathrm{g})$, and $\mathrm{Zn}(600 \mu \mathrm{g})$. This sludge conditioning was run for a month with flow rate of synthetic wastewater was 20 L/day. During this acclimatization, sludge having lighter density would be washed from the reactor and released as suspended solid. While remaining sludge on the reactor will be used for experiments.

\subsection{Experimental set up}

Sludge after acclimatization period was ready for experiment, first set up of sludge height was $60 \%$ height of reactor,. The flow rate of wastewater was $20 \mathrm{~L}$ /day by using peristaltic pump. The synthetic wastewater is set up from the market product with trade mark of Del monte and this synthetic wastewater was made by dissolving a predetermined amount of commercial sauces of Del monte brand in distilled water and followed by analyzing the content of COD to be around 2300 and $7300 \mathrm{mg} / \mathrm{L}$. pH was set up by dilute of sodium hydroxide or nitric acid to the system. This synthetic wastewater was set up for one day and every day had to be prepared equal volume and equal COD to feed to the ABR reactor. The responses of the experiment were the change of $\mathrm{pH}$ and COD of each compartment. The $\mathrm{pH}$ and COD were analyzed according to the standard method [29]. 


\section{Result And Discussion}

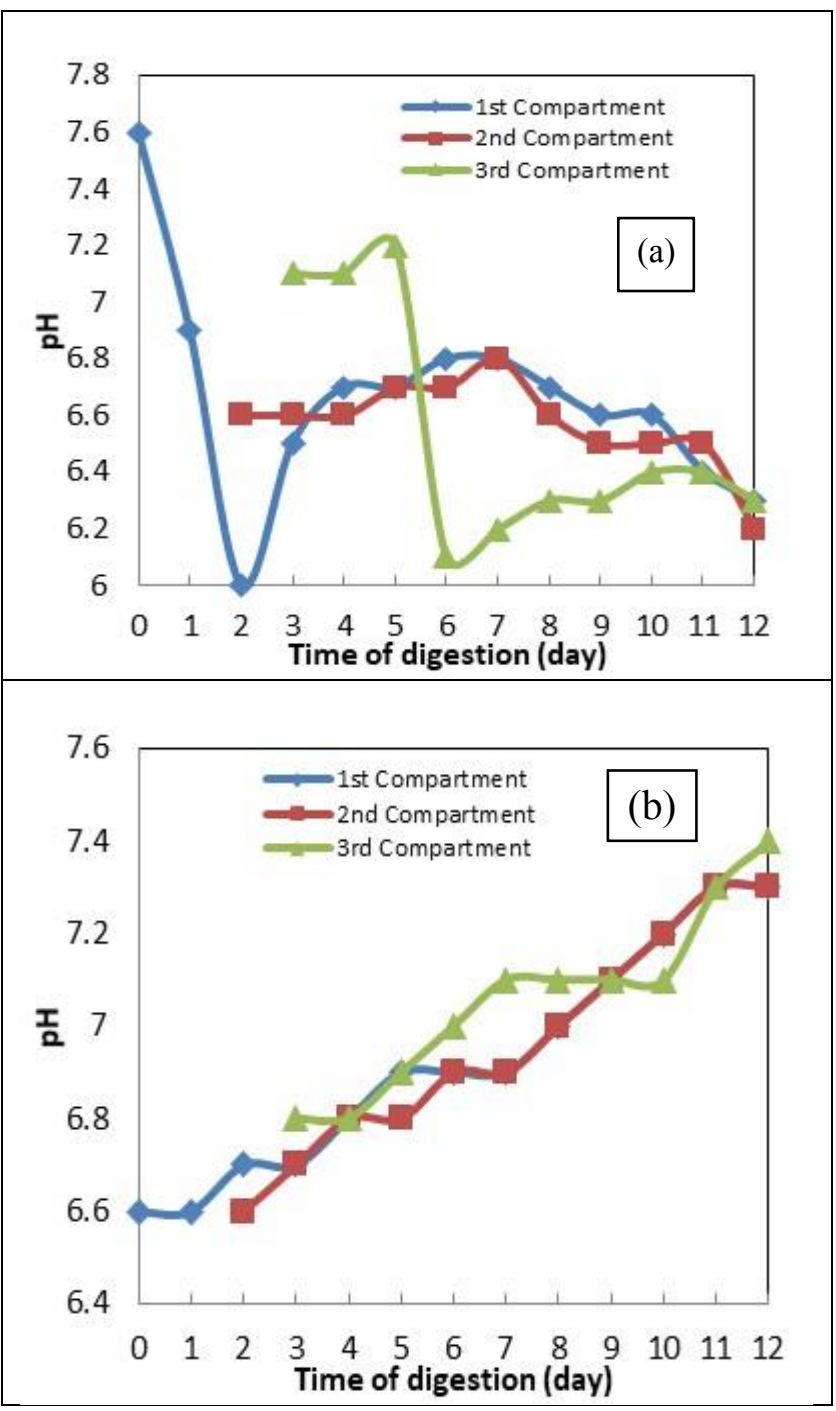

Fig. 2. Result of $\mathrm{pH}$ observation in the compartments with 60 $\%$ height of activated sludge (a). Initial COD : $2369.7 \mathrm{mg} / \mathrm{L}$ and (b). Initial COD : $7334 \mathrm{mg} / \mathrm{L}$

\section{$3.1 \mathrm{pH}$}

Observation of $\mathrm{pH}$ to the wastewater with initial COD of $2369.7 \mathrm{mg} / \mathrm{L}$ COD (Fig. 2a) showed that all of compartment 1,2 and 3 tend to decrease. The hughest decline at compartment 1 from 7.6 to 6.3 , compartment 2 (6.6 to 6.2) and compartment 3 (7.1 to 6.3). On day of $11-12 \mathrm{pH}$ for the third compartment is close to the value of about 6.2-6.3. Normally once it reached a stable $\mathrm{pH}$ conditions the the $\mathrm{pH}$ will increase [30] due to the formation of alkalinity [31]. Load of the first compartement is the most severe because of the decrease in $\mathrm{pH}$ very sharp up to the second day, food wastewater will be easily degraded so that on initial contact with the activated sludge process of hydrolysis occurs and acidogenic with a high VFA result $[32 ; 24]$. Acidogenic advanced process occurred in compartment 3 . Microorganisms on three early stages of anaerobic process has a broad $\mathrm{pH}$ range i.e. 4.0-8.5 [33]. Changes of $\mathrm{pH} 7.6$ to 6.3 still be within range for the occurrence of decomposed process into volatile fatty acids. Start the day of 11 , the $\mathrm{pH}$ for the third compartment was close the same value, this indicated that the acsidogenesis process is complete, shown in the graph of the COD that in to day of eleven the curve in the form of exponential.

While for wastewater with initial COD of $7334 \mathrm{mg} / \mathrm{L}$ (Fig. 2b), the initial $\mathrm{pH}$ of the wastewater enters in conditions of acid (6.6), the characteristic of the wastewater that is easily degraded, high content of COD leads to the formation of alkalinity from the substance of protein in foodstuffs is also fastly occurred, the rate of formation of alkalinity is more quickly then causing the rise in $\mathrm{pH}$ [34]. Based on the picture above (Fig. 2b), phases of hydrolysis is more dominant than with the stages of acidogenic with increasing $\mathrm{pH}$ results. Complementary foods with significant nutrient content will provide degradation is enough to suppress the formation of the VFA until the $\mathrm{pH}$ will increase to about 7.3-7.4 on the digestive time 11 and 12 days. The presence of the addition of the calsium ion serves to maintain the alkalinity anaerobic system will neutralize the acids are formed, and also to prevent the formation of regional acid [34].

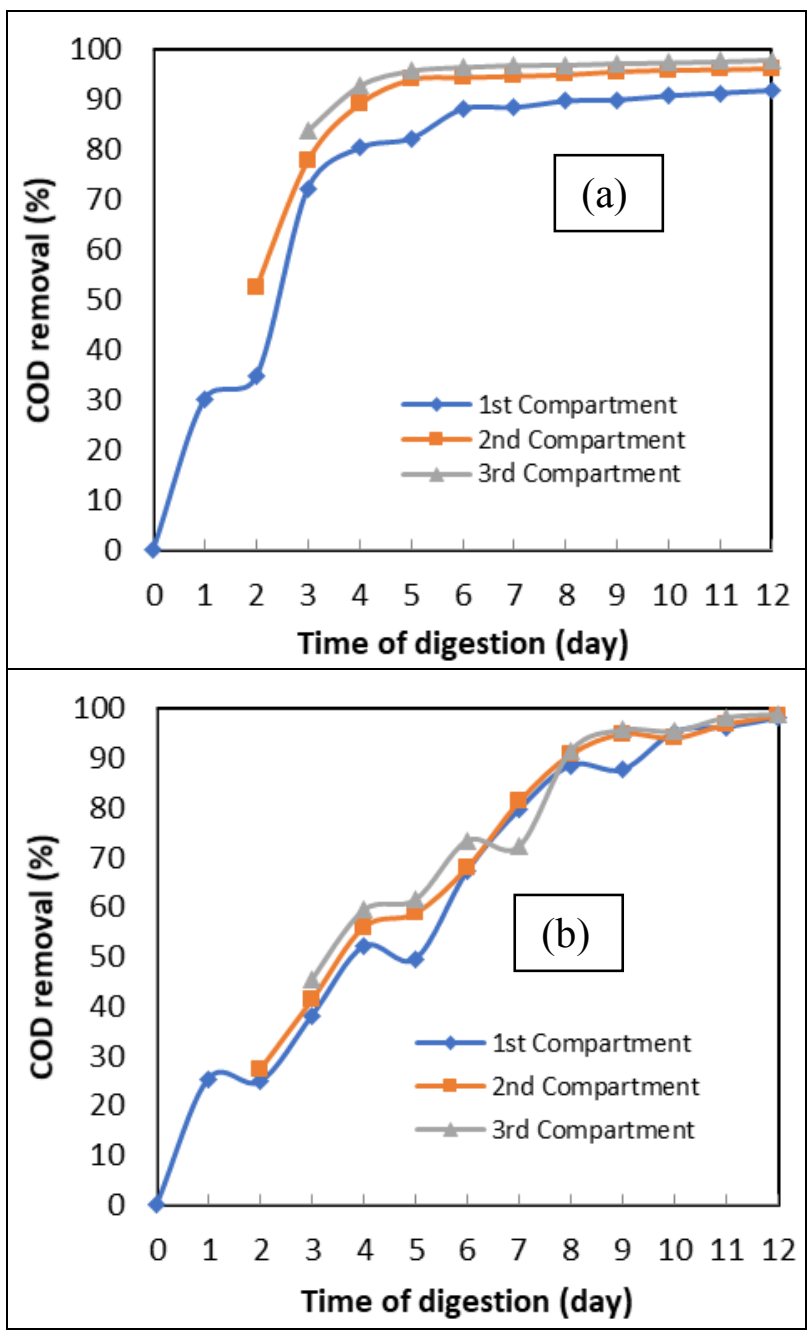

Fig. 3. Result of COD removal in the compartments with $60 \%$ height of activated sludge (a). Initial COD : $2369.7 \mathrm{mg} / \mathrm{L}$ and (b). Initial COD : $7334 \mathrm{mg} / \mathrm{L}$ 


\subsection{COD}

Observation of COD removal in the ABR system for initial COD of $2369.7 \mathrm{mg} / \mathrm{L}$ (Fig. 3a) to the digestion time of 12 days obtained results that total COD removal efficiency of the first, second and third compartments were $91.84 \%, 96.83 \%$ and $98.03 \%$. The COD removal until the fourth day is the highest with COD removal for each compartment was $80.36 \%, 89.16 \%$ and $92.80 \%$, while for the successive time addition of only slight its increase of COD removal. Curves for low initial COD expressed as a form of clear exponential curve with a stationary point between the fourth and fifth days. While for wastewater with initial COD of $7334 \mathrm{mg}$ COD/L (Fig. 3b), the performance of the removal COD of each compartment up to digestion time of 12 days was $98.15 \%, 98.51 \%$ and $98.83 \%$. In general the digestion time for 12 days, the total COD removal efficiency in $\mathrm{ABR}$, the higher organic loading the higher $\mathrm{COD}$ removal than low content of organic loading of wastewater. The curve of the COD removal to the digestion time is an exponential curve. At a low organic loading, the exponential curve shape is clearly visible at the beginning of the curve, but to a higher organic content, the curve is shifted to the right. For higher loads then the stationary point will shift to the right on the nine days. Based on the stasionary point of the curve, the degradation time is doubled for increasing organic loading of $2369.7 \mathrm{mg} / \mathrm{L}$ be $7334 \mathrm{mg} / \mathrm{L}$ or 3 times.

The highest COD removal occurred in the first compartment while each successive compartment was only removed small fractions of the remaining COD. As COD decreased in the preceding compartment, a reduction in substrate utilization rate of the microorganisms in subsequent compartments would result to the leading to a lower removal efficiency. This pehenomenon has been well supported by the bacrterial kinetics that lower substrate concentration will cause lower growth rate [35]. Studies that have been done by some researchers such as: If the organic load was increased 2-fold then needed four days to recover to its original condition [30], the efficiency COD removal in ABR reached 97.7\% [36], if HRT is increased then the efficiency COD removal is also increased [37], while for molasses with HRT increase then efficiency COD removal to be lower which is about $91.6 \%$ [33].

For ABR system, the first compartment, COD was removed through the cytogenesis and gas releases $\left(\mathrm{CO}_{2}\right.$ and $\mathrm{H}_{2}$ ), this is dominantly by acidogenic bacteria, while significant amount of COD was converted into liquid intermediate prodcuts (e.g. ethanol, butyrate and propionate) and stay in the system. The substrate in second compartment were converted into acetic acid and hydrogen by acetogen and COD was mainly removed through the conversion of intermediate products (e.g. acetic acid) to methane by the methanogenic bacteria in the third and fourth compartments [24].

Food wastewater treatment with anaerobic process in the ABR pointed out that the COD removal for the first compartment plays a very important role while successive compartments of two and beyond just reduce insignificant COD. This is useful if for anaerobic reactor design for food wastewater then it could be selected as single stage ABR similar as UASB reactor.

\section{Conclusions}

1. Anaerobic process of food wastewater treatment with ABR shows that low levels of COD content resulted the curve the exponential stabilization at 45 days digestion whereas for higher load of COD content, the curve the exponential stabilization of shifts to the right.

2. The first compartement is the main reactor to decrease the organic content of wastewater, while for the removal efficiency of the second and third compartments was not significant.

3. The increase in organic loads to 3 times resulted stabilization time 2 times

The authors gratefully acknowledge to the financial support of the Diponegoro University through research scheme of PNBP DIPA Universitas Diponegoro No. SP DIPA042.01.2.400898/2016

\section{References}

1. K. Dede, Industri Rumahan Saos Sambal Di Bandung Digerebek Polisi, okezone.com (2015, January 27).

2. PT. Indofood. Laporan UKL-UPL PT. Indofood Fritolay, Semarang (2012).

3. Peraturan Menteri Kesehatan Republik Indonesia Nomor 033 Tahun 2012 Tentang Bahan Tambahan Pangan

4. K. M. Didin, (2011, Juli 24). Bahan Pengawet Saus dan Kecap Lebihi Ambang Batas Halal Guide MUI

5. M. S. Rahman, Handbook of Food Preservation, Second edition (CRC Press, Boca Raton, London, New York, 2007).

6. B.S. Lennerz, S.B. Vafai, N.F. Delaney, C.B. Clish, A.A. Deik, K.A. Pierce, Molecular Genetics and Metabolism 114, 73-79 (2015).

7. N. Zengin, D.Yüzbaşioĝlu, F.Ünal, S.Yilmaz, S., Food and Chemical Toxicology 49, 4, 763-769 (2011)

8. A.S. Cassini, I.C. Tessaro, L.D.F. Marczak, C. Pertile, Journal of Cleaner Production 18, 3, 260-265 ()(2010)

9. Y. Zeng, C. Yang, J. Zhang, W. Pu. Feasibility investigation of oily wastewater treatment by combination of zinc and PAM in coagulation/flocculation. Journal of Hazardous Materials, 147(3)(2007), 991-996.

10. D. T. Sponza, A. Uluköy, Process Biochemistry 40 11, 3419-3428 (2005)

11. Metcalf, Eddy, Wastewater Engineering Treatment and Reuse. 4th Edition (McGraw-Hill, New York, 2003)

12. Y. Li, S.Y. Park, J. Zhu, J., Renewable and Sustainable Energy Reviews 15, 1, 821-826 (2011) 
13. L. Seghezzo, G. Zeeman, J.B. Liel, H.V.M.. Van, Hamelers, G. Lettinga, Bioresource Technology 65, 175-190 (1998)

14. T. Setiadi, Husaini, A. Djajadiningrat, Wat. Sci. Tech. 34, 11, 59-66 (1996)

15. R. Boopathy, Bioresource Technology 64, 1-6 (1998)

16. R. Grover, S.S. Marwaha, J.F. Kennedy, Process Biochemistry 34, 6-7, 653-657 (1999)

17. D.J. Batstone, V. Virdis, Current Opinion in Biotechnology 27, 142-149 (2014)

18. J.C. Akunna, M. Clark, Bioresource Technology 74, 3, 257-261 (2000)

19. I. Bodík, K. Kratochvíl, E. Gašpariková, M. Hutan, Bioresource Technology 86, 1, 79-84 (2003)

20. M. Vossoughi, M Vossoughi, M. Shakeri, M. Shakeri, M.I. Alemzadeh, I.Alemzadeh, Analysis 42, 811-816 (2003)

21. Ö.S.Kuşçu and D.T. Sponza, D. T., Enzyme and Microbial Technology 36, 7, 888-895 (2005)

22. M.I. Baloch, J.C. Akunna, and P.J. Collier, Bioresource Technology 98, 9, 1849-1855 (2007)

23. S. Chelliapan, T. Wilby, P.J. Sallis, Water Research 40, 3, 507-516 (2006)

24. G.F. Zhu, J.Z. Li, P. Wu, H.Z. Jin, Z. Wang, Bioresource Technology 99, 17, 8027-8033 (2008)

25. D. Cui, Y-Q. Guo, H-S. Lee, W.-M. Wu, B. Liang, A.-J. Wang,H.Y. Cheng, Bioresource Technology 163, 254-261 (2014)

26. I.V. Skiadas,H.N. Gavala, G. Lyberatos, Water Research 34, 15, 3725-3736 (2000)

27. I. Sumantri, P, Purwanto, Budiyono, AIP Conference Proceedings 1699, 050017 (2015)

28. J. Ma., L. J. Mungoni., W Willy Verstraete., M. Carballa, Bioresource Technology 100, 3477-3482 (2009)

29. APHA, Standard Methods for the Examination of Water and Wastewater, 21st ed (2012)

30. G.D. Ji., T.H. Sun, J.R. Ni, J.J. Tong, Bioresource Technology 100, 3, 1108-1114 (2009)

31. S. Ozdemir, K. Cirik, D. Akman, E. Sahinkaya, O. Cinar, Bioresource Technology 146, 135-143 (2013)

32. P. Thanwised., W. Wirojanagud., and A. Reungsang, International Journal of Hydrogen Energy 37, 1550315510 (2012)

33. M. Pirsaheb, M. Rostamifar, A.M. Mansouri, A.A.L. Zinatizadeh, K. Sharafi, Journal of the Taiwan Institute of Chemical Engineers 47, 137-148 (2015)

34. F. Xu., Z. Huang., H. Miao., H. Ren., M. Zhao., and W. Ruan, Journal of Environmental Sciences 25, 10, 2031-2040 (2013)

35. K. Saritpongteeraka, S. Chaiprapat, Bioresource Technology 99, 8987-8994 (2008)

36. W. Cao, M. Mehrvar., Chemical Engibeering Research and Design 89, 1136-1143 (2011)

37. Z. Li,., D. Suzuki,., C. Zhang,., N. Yoshida,., S. Yang, A Katayama, Journal of Bioscience and Bioengineering 116, 5, 602-609 (2013) 